\title{
Drivers of Hotel Employee Retention: A Comparative Study
}

\author{
Karen M. Fernandez ${ }^{1, *}$, Kumutinee Worasuwan ${ }^{2}$ \\ ${ }^{1}$ College of Hotel/Restaurant and Tourism Management, Imus Institute of Science and Technology, 82 Nueno Avenue, \\ City of Imus, Cavite 4103, Philippines \\ ${ }^{2}$ Bachelor of Business Administration Program, Burapha University International College, 169 Longhard Bangsaen Road Saensook, \\ Chonburi 20131, Thailand
}

Copyright $\mathrm{C} 2017$ by authors, all rights reserved. Authors agree that this article remains permanently open access under the terms of the Creative Commons Attribution License 4.0 International License

\begin{abstract}
The Thai economy is on the rise and the labor market is getting more competitive, partly because of the government's policy of raising minimum wage, according to a recent survey. In many ways the Philippines has achieved better progress than other developing countries. It has become industrialized nation integrated in the world economy and has somewhat moved away from agriculture. But somehow the labor turnover issues in both countries have been increasing especially in the hospitality industry. One of the most critical issue facing organizations today is how to retain the employees they want to keep. Employees retaining is the most imperative target for the organization because hiring of qualified candidate is essential for organization but their retention is more important than hiring, because a huge amount is spending on the orientation and training of the potential employees. Employee retention in the hospitality industry is a persistent problem which management can reduce by applying effective managerial and leadership practices as a means of generating employee satisfaction. Compare with other sectors where positions are mostly full-time, specialized and operate during traditional business hours, the hospitality workforce is labor intensive, and characterized by high levels of casualization diverse skill requirement from unskilled to highly specialized employees, customer contact oriented, and twenty-four hour seven days per week operation are some of the causes of high turnover. Worldwide researchers have suggested that employee turnover is among the highest in hospitality industry. When employees leave, valuable knowledge is lost and even guests may follow the departing employee. Hoteliers who have actively find ways to retain employees gain a sustainable competitive advantage. The study compares the employee retention information from the managers of selected hotels in two Southeast Asian countries, Thailand and Philippines. An empirical research is conducted to analyze and assess the best leadership practices used by hotel managers on retaining their employees. This study will lead in formulating strategies
\end{abstract}

that will also contribute to the existing body of knowledge of the leadership and management practices in hotel employee retention.

Keywords Employee Retention, Employee Turnover, Managerial and Leadership Practices, Hospitality Industry

\section{Introduction}

Employee commitment, productivity and retention issues are emerging as the most critical workforce management challenges of the immediate future, driven by employee loyalty concerns, corporate restructuring efforts and tight competition for key talent. For many firms, "surprise" employee departures can have a significant effect on the execution of business plans and may eventually cause a parallel decline in productivity. This phenomenon is especially true in light of current economic uncertainty and following corporate downsizings when the impact of losing critical employees increases exponentially (Caplan and Teese, 1997 [3]; Ambrose, 1996 [1]; Noer, 1993 [12]).

It is noticed that reasons for employee turnover may vary from external environmental factors such as economy that influence the business organization (Pettman, 1975 [14]). Moreover, the other factors that influence employee turnover in organizations include the demographic variables, job satisfaction, remuneration, work-life balance, promotion and working condition (Pettman, 1975 [14]; Mobley 1982 [11]). Any of the above factors could be the reasons, but the decision process to leave or stay in the organization is to be periodically examined to understand the specific reasons that prompted them to take.

Employee retention refers to the ability of an organization to retain its employees; it is related to the efforts by which employers attempt to retain employees in their workforce. Employee retention is the various policies 
and practices which let the employees stick to an organization for a longer period of time. Today, retention is particularly challenging due to an aging work force and a growing imbalance in the supply and demand of qualified personnel (Padron, 2004 [13]). As every organization invests time and money to groom a new joiner, the organization is completely at loss when the employees leave their job once they are fully trained.

The hospitality sector is one of the world's fastest-growing industries. However, huge problems still exist in attracting and retaining a skilled workforce (Druce, 2007 [6]). Jesus (2011) [8] has stated that the issue of labor shortage is posing great obstacles to the hotel industry, which has given rise to numerous human resources management challenges for hotel operations and could potentially hinder the industry's overall development. As turnover crises have had great impacts on the hospitality industry, most hotel executives have long understood the value of retaining top notch employees. Countless studies have linked high employee retention to vital results such as improved service quality and operational effectiveness, reduced overtime and hiring costs, as well as increased customer satisfaction and guest experience ratings. Strong retention is highly correlated with strong company performance.

This study compares the employee retention information from the managers of selected hotels in two Southeast Asian countries, Thailand and Philippines with the aim of identifying strategies that will also contribute to the existing body of knowledge of the leadership and management practices in hotel employee retention.

\section{Literature Review}

Previous researchers reported that there is a high staff turnover of employees working in the hotel sector (Davidson \& Wang, 2011 [6]; Mohsin, Lengler \& Kumar, 2013 [16]; Pearlman \& Schaffer, 2013 [19]). This is detrimental towards hotels' management costs and many prospective employees may not find working in hotels, the right choice. High employee turnover costs that may hamper organisational success include financial costs (resulting from Human Resource process of replacing staff), inconsistent service quality (the performance of different staff may differ), and the resulting loss in customer loyalty (Kuria, Alice \& Wanderi, 2012 [12]; Mohanty \& Mohanty, 2014 [15]; Yam \& Raybould, 2011 [21]; Yang, Wan \& Fu, 2012 [22]).

Some researchers reported the probable cause of hotels' high employee turnover to include long working hours, perceived unfair compensation, minimal growth opportunities, and poor working relationships between superiors and subordinates (AlBattat, Som \& Halalat, 2014 [1]; Davidson \& Wang, 2011 [6]; Kuria et al., 2012 [12]; Mohanty \& Mohanty, 2014 [15]).
In today's turbulent workplace, a stable workforce becomes a significant competitive advantage. If an organization has unstable workforce conditions, it's forced to invest thousands of dollars in recruiting, orienting, training, overtime and supervision. Those dollars come right off the 'bottom line' (Reichheld, 2001; Dibble, 1999; Herman, 1999).

Without continuity, organizations don't have ongoing close relationships with customers; customer loyalty is fragile; managers are stressed; conflict is more likely; efficiency is hampered. Such challenges make it difficult for an organization to compete in the marketplace.

Arguably, the most valuable and volatile asset is a stable workforce of competent, dedicated employees. Longevity gives a company a powerful advantage; depth of knowledge gives organization strength. The loss of a competent employee is increasingly difficult to replace with someone of comparable competence-even with an effective succession planning process. With a volatile labor market and competition for good people, organizations are forced to hire persons with less competence. If this scenario repeats itself enough, the aggregate competence and capacity of the organization's workforce will gradually diminish-along with the ability to meet customer expectations (Ambrose, 1996). Dissatisfied customers leave, and take the organization's cash flow and profits with them.

Employee retention is an effort by a business to maintain a working environment which supports current staff in remaining with the company. Moreover, employee retention refers to policies and practices companies use to prevent valuable employees from leaving their job. It involves taking measures to encourage employees to remain in the organization for the maximum period of time. As similar as Zineldin (2000), retention has been viewed as an obligation to continue to do business or exchange with a particular company on an ongoing basis. Many employee retention policies are aimed at addressing the various needs of employees to enhance their job satisfaction and reduce the substantial costs involved in hiring and training new staff. Hiring knowledgeable people for the job is essential for an employer. But retention is even more important than hiring.

To retain top talent has become a primary concern for many organizations today. Managers have to exert a lot of effort in ensuring the employee's turnover are always low, as they are gaining increasing awareness of which, Meaghan and Nick (2002), employees are critical to organization since their values to the organization are not easily replicated. Arthur (1994) has confirmed that there are various studies showed how high employees involvement is can relate to the intention of leaving an organization. As far as, organizational commitment has been considered as one of the most important indicator of turnover and intention to leave. It was found that employees who were more committed to their 
organizations had lower intention to leave than those who were not. Clarke (2001) has indicated that employees will retain in their organization if he or she has a good relationship with the people he or she is working around with. However, lacking of opportunities to learn and self-development in the workplace is one of the factors for employee dissatisfaction which leads to turnover.

Today managers must take care of their employees' personal feelings toward the job and satisfaction levels from their working conditions, superiors and peers, as these are the keys to ensure employee retention. The organizations are suggested to provide team building opportunities, where interaction and discussion can be carried out not only within but outside their working hours (Johns et al 2001).

\section{Materials and Methods}

The purpose of this primarily research is to identify strategies in hotel employee retention. Therefore, an in-depth interview has been conducted to identify drivers of employee retention in hotel industry. Twenty managers were interviewed to find out drivers of retention and best practices of human resources management programs that will help hotels achieve desired retention results. The paper presents a detailed assessment of analysis of different approaches of managers in the cities of Thailand and Philippines and makes a comparison using a particular parameter.

\section{Results and Discussion}

\section{Management Strategies in Hotel Employee Retention}

\subsection{Know Thyself}

The starting point for improved employee retention is based on the simple premise that the best way to increase retention is to hire the right people for the job. And that requires understanding the criteria for success on the job in the specific context of the organization. This goes beyond a basic understanding of the tasks, duties, and methods necessary to do the work. Those only provide the basics.

Knowing thyself requires the deeper understanding that comes from examining a broad range of factors that are ultimately more critical to success. These include honest assessments of company culture, managerial style and organization values - both the idealistic objectives listed on company posters and advertising campaigns and the demonstrated behaviors of managers and employees. It also requires understanding the unique criteria found in engaged, top performers - such factors as competencies, strengths, behavioral style, values, attitudes and ambitions.

\subsection{Listen}

Listening is a key to improved employee retention because it creates an environment where employees feel valued and because it provides managers with insights into ways to continuously improve the workplace.

By seeking first to identify and understand the needs and interests of the employees, it can create an environment that lets them voice their thoughts and opinions. And the more they share the more information it may have to create innovative solutions for motivating and engaging. But it is more than just listening to the words they say. To become an effective listener, managers must go beyond literal content and learn to hear the intent, the emotions, and the deeper meaning others are trying to communicate.

\subsection{Engage}

Engagement is intrinsically motivated and is about having pride in the organization and being willing to exert extra effort on behalf of the company. It's also about feeling responsible for the work product and outcomes, feeling inspired to do one's best and believing they can make a positive impact.

Managers drive engagement when they inspire enthusiasm and when they ask for input into decision-making in their departments. They also improve engagement when they offer opportunities to develop new knowledge and skills as well as find ways for employees to impact the quality of the work or service.

\subsection{Provide Autonomy}

Employees are at their best when they are given autonomy. They want to know their managers trust them to do their work. They want their managers to trust that they understand what they need to get done and that the managers are okay letting them do it the way they want to do it.

Traditional notions of management, like the carrot and stick, are great if the managers want compliance. But if they want engagement, the key driver of intrinsically-driven high performance and increased retention, then self-direction works better.

\subsection{Personal and Professional Development}

Development is considered as gaining new skills and taking advantage of many different methods of learning that benefit employees and the organization alike. The availability of employees in terms of skill development opportunities and career movement is the key attractors to organizations. If an organization does not recognize the individual's need and desire to grow, then development becomes a primary reason for resignation. Therefore, the organization should support people to develop their skills, knowledge, and even advance in their career. 
By offering career development opportunities, employers can help employees enhance their employability in the internal and external labor market and develop their own personal competitive advantage. Many employees look out for employers who provide training and skill development activities that facilitate career improvement. When they receive such opportunities, employees are likely to commit to the organization. The personal and professional development opportunities offered by employers reduced turnover intentions.

\subsection{Trust and Reciprocity}

Then managers can work on trust and reciprocity by always taking into consideration the needs and the interests of their employees before making any decisions which are in regard to them. As well as, the managers have to show at least their good intention to their employees and try to find solutions that can satisfy both employees and organization.

As well as, the individuals should feel satisfied with the group they are in and with the role and the status they receive in the group. This relational orientation and team atmosphere is also fostered by the attitudes of most managers who are keen on a hands-on approach. Besides that, the organizations should provide a safe and proper work place environment and also respond to the individual's needs, and not to the needs of a group.

\subsection{Communication}

Once employees are given autonomy, they have the necessary information to assess different situations and they are empowered to make decisions and take responsibility. They feel they are able to communicate with both immediate colleagues and senior management in an open and honest way through a two-way open-door policy.

Clearly, effective communication encourages staff to adjust their assumptions of what is expected of them. So, the management of expectations is one of the most important ways for managing employee retention.

\section{Conclusions}

By applying these strategies, individual managers can make a profound impact on employee retention. They create a climate that leads to employees who are more likely to share the organization's values, who understand their role, who are more satisfied and engaged, and who perform at a higher level of quality in serving hotel guests.

Ultimately the most successful and enduring organizations in business are those that have a common sense of mission, a deep respect for their employees and customers, and put time, energy, and money into building a highly engaging environment. They carefully select the "right people" with lots of hard work, and once people join they take the time to make sure they have development opportunities to move up the value curve.

Staff retention strategies aim to keep the staff that the organization wants by satisfying their needs. Therefore, organization needs to assess its structure and management to develop ways in which to improve employee retention. In effective strategies to improve employee retention involve attention to such areas as: Know Thyself, Listen, Engage, Provide Autonomy, Trust and Reciprocity, and Communication.

\section{REFERENCES}

[1] AlBattat, A.R. Som, A.P.M., and Halalat, A.S. Higher dissatisfaction higher turnover in the hospitality industry. International Journal of Academic Research in Business and Social Science, 4 (2), 45-52, 2014.

[2] Ambrose, Delores. Healing the downsized organization, Three Rivers Press, New York, 1996.

[3] Arthur, J. Effects of human resource systems on manufacturing performance and turnover. In Academy of Management Journal, v37, pp. 670-87, 1994.

[4] Caplan, Gayle and Teese, Mary. Survivors: How to keep your best people on board after downsizing, Davies-Black Publishing, Palo Alto, 1997.

[5] Clarke, K.F. What businesses are doing to attract and retain employee becoming an employer of choice. Employee Benefits Journal, March, 34-37., 2001.

[6] Davidson, M.C.G. and Wang. Sustainable labor practices? Hotel human resource managers views on turnover and skill shortages. Journal of Human Resources in Hospitality and Tourism, 10 (3), 235-253, 2011.

[7] Dibble, Suzanne. Keeping your valuable employees: Retention strategies for your organization's most important resource, John Wiley and Sons. Inc., New York, 1999.

[8] Druce, C. Skills strategy a positive step, say employers, Caterer and Hotelkeeper, 197 (Issue 4467), 12, 2007.

[9] Herman, Roger E. Keeping good people: Strategies for solving the \#1 problem facing business today, Oakhill Press, Winchester, VA, 1999.

[10] Jesus, S. Boys for the Jobs. Macau Business, 83, 70-72, 2011.

[11] Johns, G.H., Gutmann, M.E., Dewald, J.P. and Nunn, M.E. Career Retention in the Dental Hygiene Workforce in Texas Journal of Dental Hygiene, Spring, 75, i2, 135-43, 2001.

[12] Kuria, S., Alice, O., and Wanderi, P.M. Assessment of causes of labour turnover in three and five star-rated hotels in Kenya. International Journal of Business and Social Science, 3 (15), 311-317, 2012.

[13] Meaghan Stovel and Nick Bontis. Voluntary turnover: knowledge management-friend or foe? J.intellect. Cap. 3 (3): 303-322, 2002. 
[14] Mobley, W. H. Employee Turnover: Causes, Consequences, and Control. Addison-Wesley Publishing, Philippines, 1982.

[15] Mohanty, S. and Mohanty, K. Employee retention: a key driver to growth of tourism and hospitality in Odisha. International Journal for Innovation Education research, 2 (12), 94-112, 2014

[16] Mohsin, A., Lengler, J., and Kumar, B. Exploring the antecedents of intentions to leave the job: the case of luxury hotel staff. International Journal of Hospitality Management, 35, 48-58, 2013.

[17] Noer, David. Healing the wound-Overcoming the trauma of layoffs and revitalizing downsized organizations, Jossey-Bass, San Francisco, 1993.

[18] Padron, T. Retention of Employees in the Wisconsin Restaurant Industry. Unpublished Master's Thesis, University of Wisconsin-Stout, Menomonie, 2004.
[19] Pearlman, D.M. and Schaffer, J.D. Labor issues with the hospitality and tourism industry: a study of Louisiana's attempted solutions. Journal of Human Resources in Hospitality and Tourism, 12 (3), 217-242, 2013.

[20] Pettman, B. O. Labour Turnover and Retention, John Wiley \& Sons, New York, 1975.

[21] Yam, L. and Raybould, M. Employee retention: job embeddedness in the hospitality industry. 9th ApacCHRIE Conference. Hospitality and tourism education: from a vision to an icon.

http://epublications.bond.edu.au/business_pubs/504, Hong Kong, June 2015.

[22] Yang, J., Wan, C., and Fu, Y. Qualitative examination of employee turnover and retention strategies in international tourist hotels in Taiwan. International Journal of Hospitality Management 31, 837-848, 2012.

[23] Zineldin, M. TRM Total Relationship Management, Student litterateur, Lund, 2000. 